\title{
Presentation, Representation, and Museumification in Heritage Tourism: The Case of Hongkeng Hakka Earth Building Folk Cultural Village
}

\author{
Lijun Zhang
}

\begin{abstract}
UNESCO's placement of the large, multi-story communal vernacular buildings known as tulou (土楼, rammed earth building) on its World Heritage List, and the touristic development that followed, has produced great social transformations among the Hakka people of Southeast China who reside in these impressive dwellings. My research explores the impact of UNESCO-inspired tourism on community life in Hongkeng village (Yongding Hakka Tulou Folk Culture Village). In this brief essay, I explore the local reshaping of space and social relationships to illustrate the ways that heritage tourism transforms everyday life and local culture. My special interest in the larger project from which this essay draws is the ways that local people negotiate such transformations. The negotiation process involves local people adapting to the new heritage phenomenon and navigating situations of frequent cultural contact and regular conflicts of interest. On the one hand, heritage and tourism contribute to the museumification of local life and culture. Local government and natives consciously or subconsciously represent their identity and tradition as well as produce localness through the decoration and reshaping of local living space. On the other hand, heritage tourism activities result in new forms of social interaction that challenge local genealogical social structure and family relationships. In such circumstances, new modes and patterns of community interaction and local cultural practices are generated under the transformative forces of heritage and tourism. My investigations into the spatial, cultural, and social spheres of local life in Hongkeng aim to help understand the transformation of an indigenous community while it is engaging in (and with) heritage practices such as listing, landmarking, representation, historical recreation, cultural commodification, and touristic management.
\end{abstract}

[Keywords: China; Hakka; folk museums; heritage; heritage tourism; vernacular architecture; world heritage areas. Keywords in italics are derived from the American Folklore Society Ethnographic Thesaurus, a standard nomenclature for the ethnographic disciplines.]

In this brief essay, I aim to illustrate the processes of presentation, representation, and museumification through individual agency at a Chinese cultural heritage site. I examine the ways that local daily life is transformed into heritage, artifact, and performance and explore how

\footnotetext{
${ }^{*}$ The peer-reviewed contribution was accepted for publication on June 30, 2016. The work is licensed under the Creative Commons Attribution 4.0 International License. To view a copy of this license, visit $\mathrm{http} / / /$ creativecommons.org/licenses/by/4.0/
} 
local living space is transformed into an idealized re-presentation of itself. In these contexts, my concern is with local people's metacultural relationship to their life world. ${ }^{1}$ My selected research site, "Hongkeng Hakka Earth Building Folk Cultural Village," is located in a mountainous area of southeast China. Specifically, the well-known village is in Yongding County in southwest Fujian Province (Figure 1). It is a residential area with a high degree of Hakka ethnic concentration. People living in Hongkeng village belong to a single lineage and have Lin as their family name. The village was designated as a UNESCO World Cultural Heritage site in 2008 because of the large, multi-story, communal, vernacular buildings known as tulou (土楼, rammed earth building) located in the area (Huang 2009; Zhang 2014; UNESCO 2008).

The term tulou usually refers to the area's distinctive vernacular architectural style characterized by a rammed earth techniques manifest at a huge physical scale (Figure 2). I say usually because some people in the region also use the term tulou to refer to smaller houses. Tulou are built of earth and wood as basic building materials and are used for communal dwelling at various sites throughout the region. Since being granted special cultural heritage designation in 2008, Fujian Tulou, with the first letters capitalized, became a legitimated term used by UNESCO, by governments at all levels, and in various media to refer to the designated tulou and tulou "clusters," which include forty-six buildings and six multi-building tulou clusters.

The UNESCO designation and the touristic development that followed, has produced great social transformations among the local Hakka people. The village used to be primarily an agricultural community dependent upon the growing of rice and a few cash crops such as tea and persimmons. After being designated as a UNESCO heritage site, this village of about 2800 residents has turned into what locals and tourists alike both call a "living museum." This once relatively isolated community is now much more fully exposed to, and connected with, the outside world. With a large number of Chinese and international tourists visiting, as well as the ongoing reframing and reconstruction of the residential village as a folk culture village (Pan 2011), this village is gradually transforming from an agriculture-based community to a serviceoriented destination or what Pál Nyíri (2006) calls a scenic spot.

In the decades before the World Heritage nomination, the now highly valued houses had been gradually depopulated and in some cases even abandoned. Tulou were regarded as out-of-date architecture by local people, especially by the younger generations. In contrast to old-fashioned tulou, single-family houses made of bricks and concrete are the new architecture style preferred by most local people. When cultural experts and government officials "discovered" the special value of tulou, and designated them as expressions of local and regional heritage, they were given what Barbara Kirshenblatt-Gimblett describes as "a second life" (1998a, 7; see also 2006). Now local people have moved back to their tulou not because of a desire for living comfort or convenience, but because of the new meanings and values brought into play by the label "world heritage." Tulou have been revalued, taking on new significances in a tourism-based, culturefocused economy. 

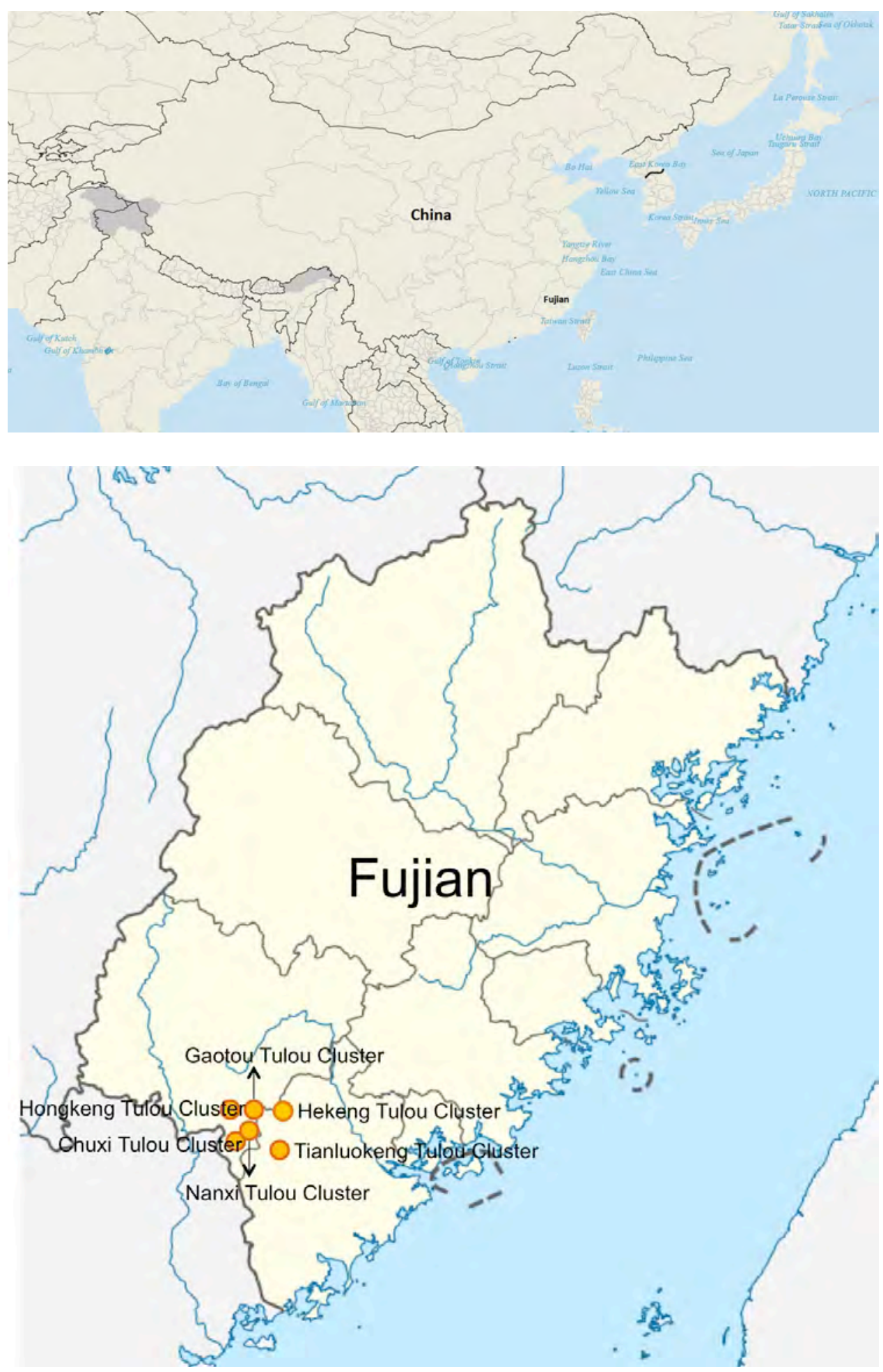

Figure 1: Location of Fujian Tulou sites. 


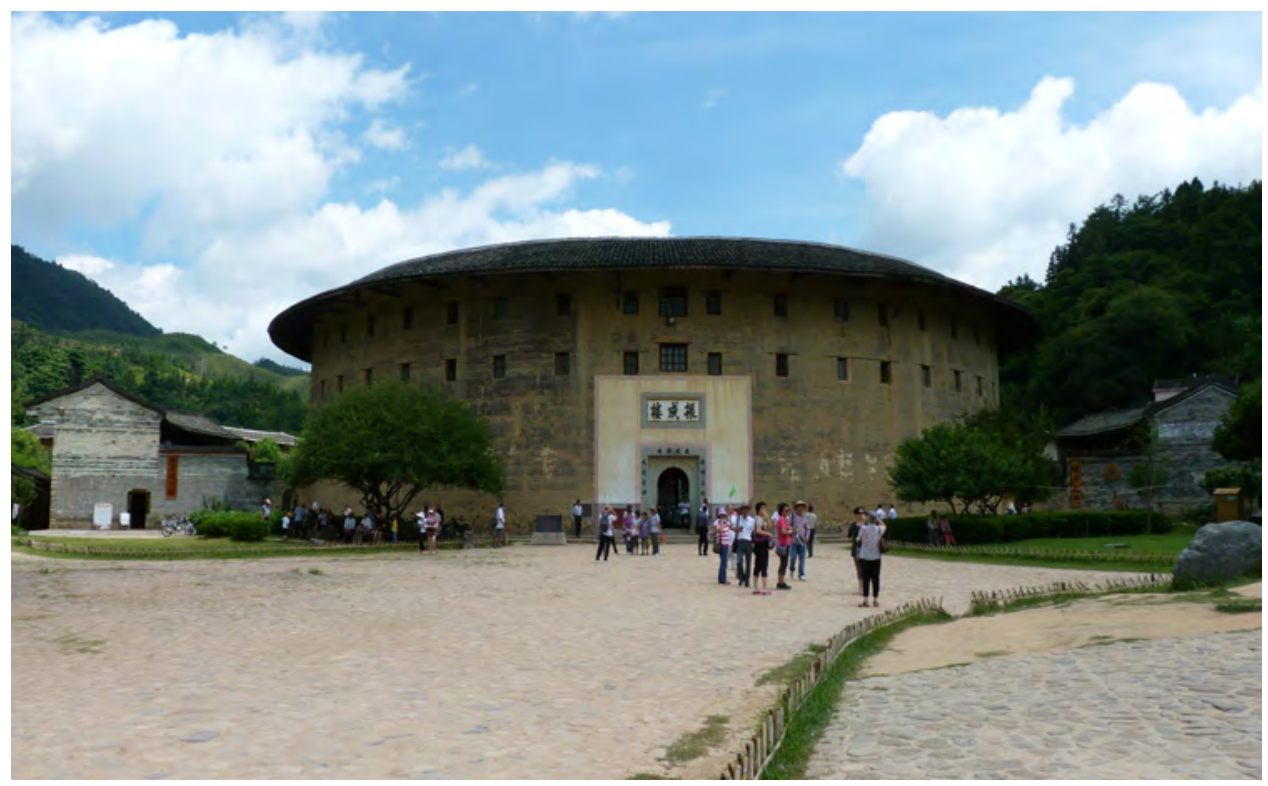

Figure 2: The largest tulou in Hongkeng Village, the Zhencheng building (All photos are by the author).

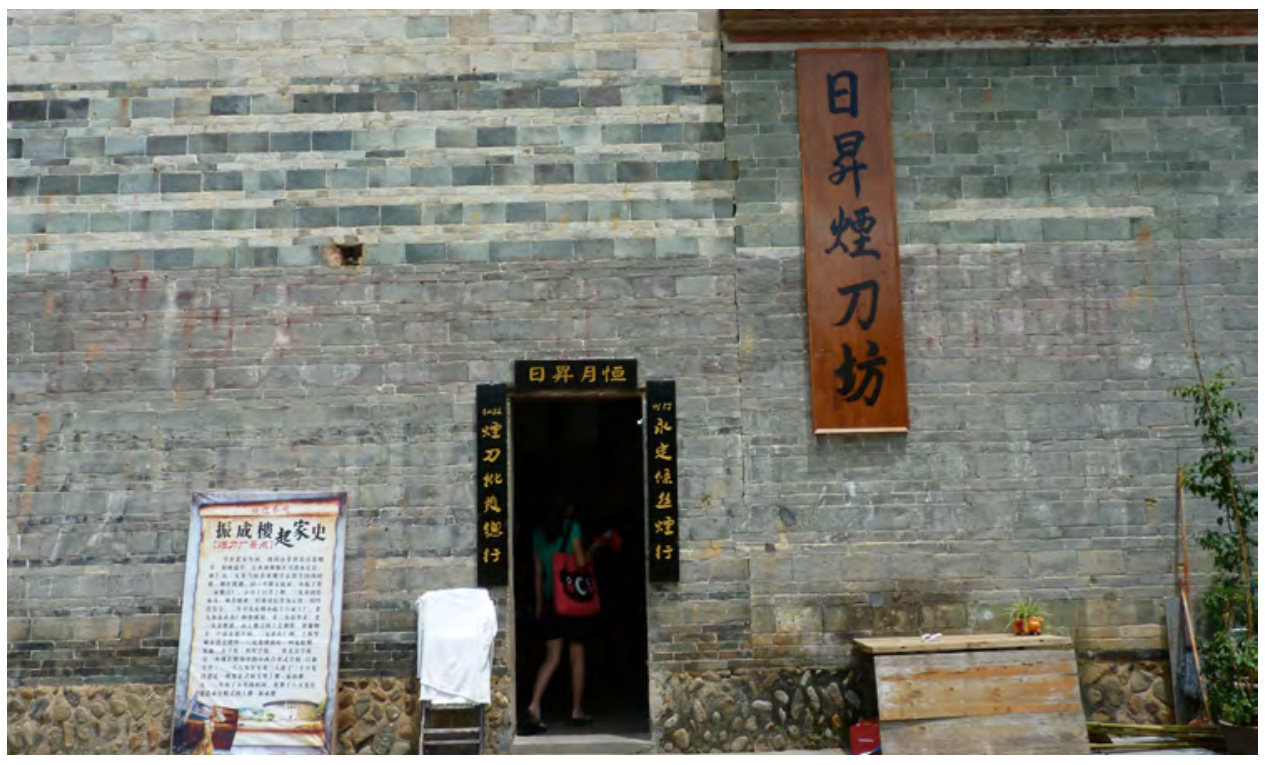

Figure 3: Risheng Tobacco Cutter Workshop.

The touristic exploitation that followed this metacultural transvaluation permits local people to make a living on the basis of newly recognized heritage assets; it also enables them to generate a new sense of cultural identity pride and to recognize new forms of cultural expression. Now tulou are celebrated for their architectural value and for the value of both expressing cultural difference and local particularity while concurrently being embraced by some locals and by diverse global actors as a kind of global common property. These value transformations have turned Hongkeng and other tulou world heritage sites into destinations. ${ }^{2}$ This is the basis on which local people achieve their economic goals through the display of tulou and other 
expressions of local folk culture in tourism. Public exhibition of local culture and of family history are a new form of cultural expression that are closely connected to the new form of daily economy manifest in heritage tourism.

My discussion can be grounded through an example of such display in the folk cultural village. Figure 3 illustrates a small cultural display exhibited by the residents living in the penthouse attached to one of the biggest tulou in the village. This tulou is known as the Zhencheng building (Figure 2). There are two households living in the building. Each household owns half of the structure. The building used to be a family workshop in which residents engaged in simple commodity production-processing tobacco and manufacturing tobacco cutters. A gate on the structure's west side connects the building to a side door on the east side of the main structure. The residents opened an extra door in the north side of the building in order to provide easier access to the house for tourists. Above the door is a wooden tablet labeling the section as the Risheng Tobacco Cutter Workshop (risheng yandaofang 日升烟刀坊). A board is placed in front of the door introducing the "Family History of Zhencheng Building (zhenchenglou qijiashi 振成 楼起家史)". On the top of the board are characters welcoming tourists to visit the "scenic spot of tobacco cutter factory (yandaochang jingdian 烟刀厂景点).” The self-marking of the place as a "scenic spot" gives the former workshop an authoritative sense and decontextualizes it from the rest of the village.

Figure 4 shows the tea table in the small living room near the north entrance of the building. There is a tea tray full of tea artifacts and, in front of the tea tray, small bronze figures are set on the table to display the process of processing dried tea. There are six such tea tables in the relatively small building to accommodate the large number of tourists coming to the building. The rooms on the east side of the building used to be enclosed space. The residents tore down the walls facing the passage and turned the rooms into open space so that tourists can easily see the interior of the rooms decorated with pictures, photos, and calligraphy, and to sit down and drink tea with the hosts (Figure 5).

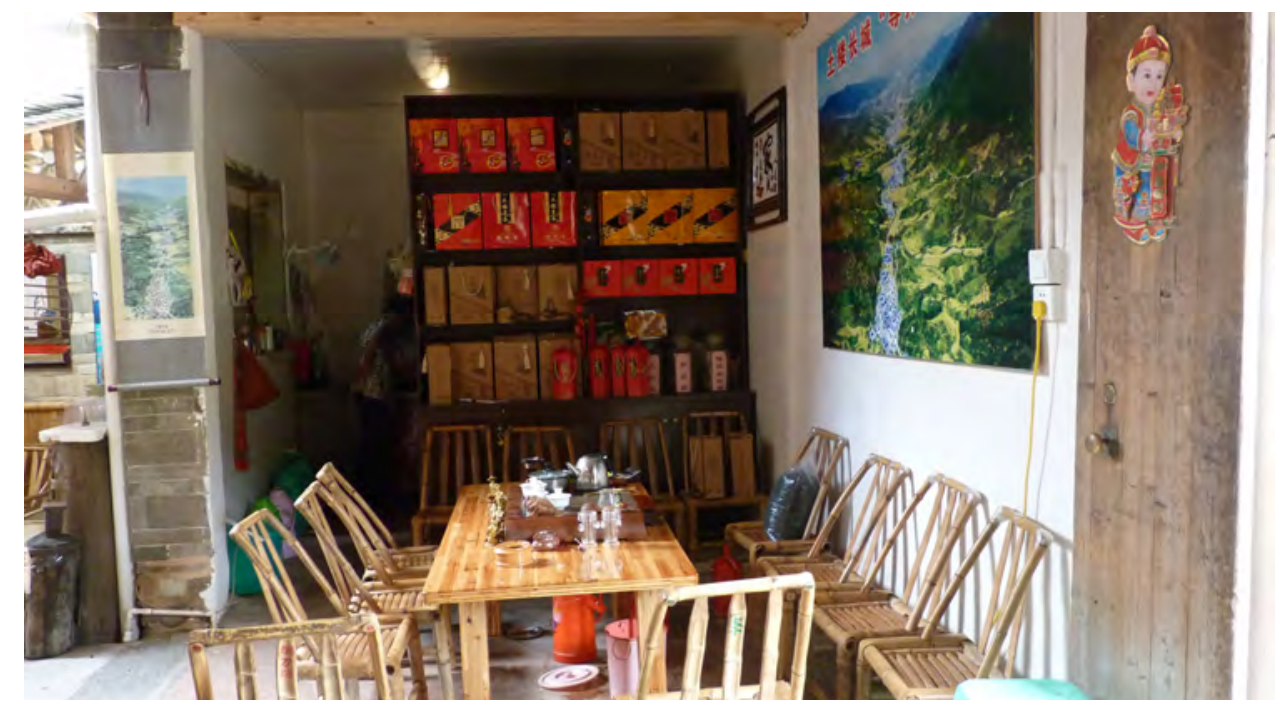

Figure 4: Tea table at Risheng Tobacco Cutter Workshop. 


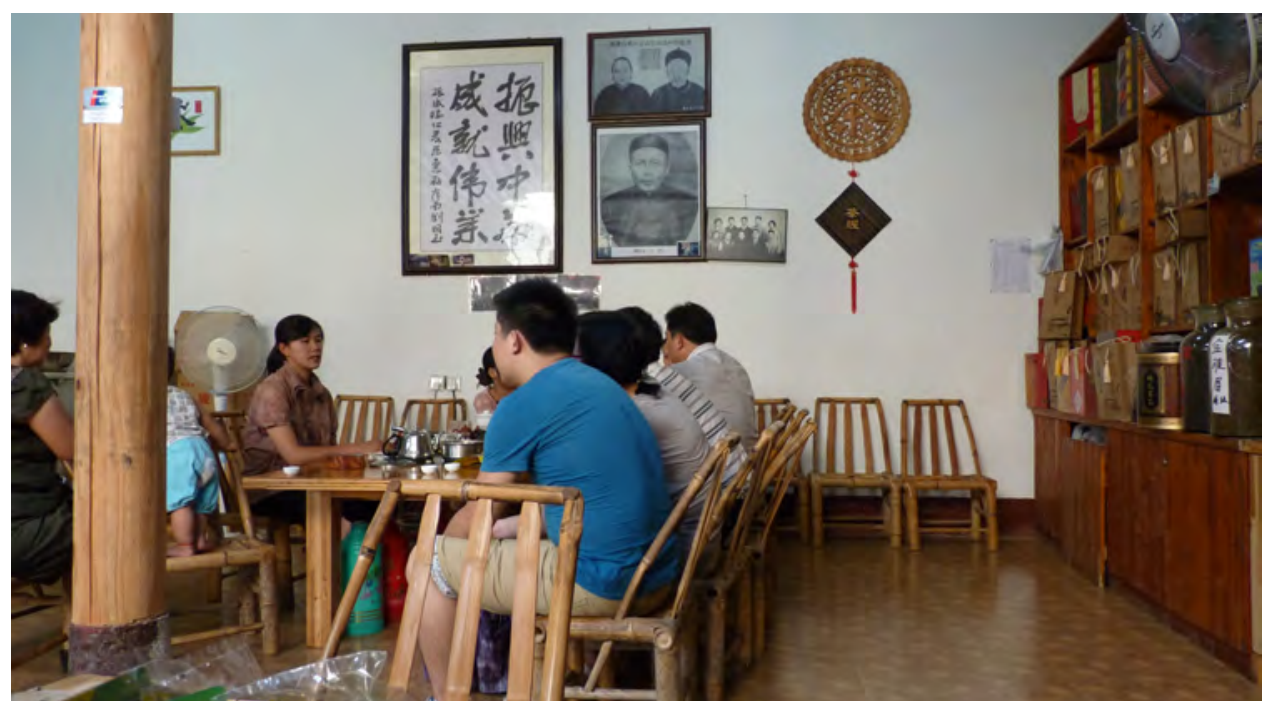

Figure 5: Tulou residents serving tea to tourists.

The intended highlight of the building is the exhibition of tobacco cutters, which are displayed in chronological order. The exhibition, along with the remodeling of the building, started in June 2009, one year after tulou were given World Heritage status. The residents of the Zhencheng building used to work as migrant workers in a city. The tobacco cutters had been stored and forgotten in the building's storage rooms upstairs for a long time. When the residents came back home to start their tourism business in 2009, they dug out the cutters and cleaned them for display. The artifacts are plainly exposed to the visitors with only a piece of white paper stuck in front to mark which generation the tobacco cutter is associated with. A signboard introducing the family history contextualizes the exhibition artifacts in written form (Figure 6).

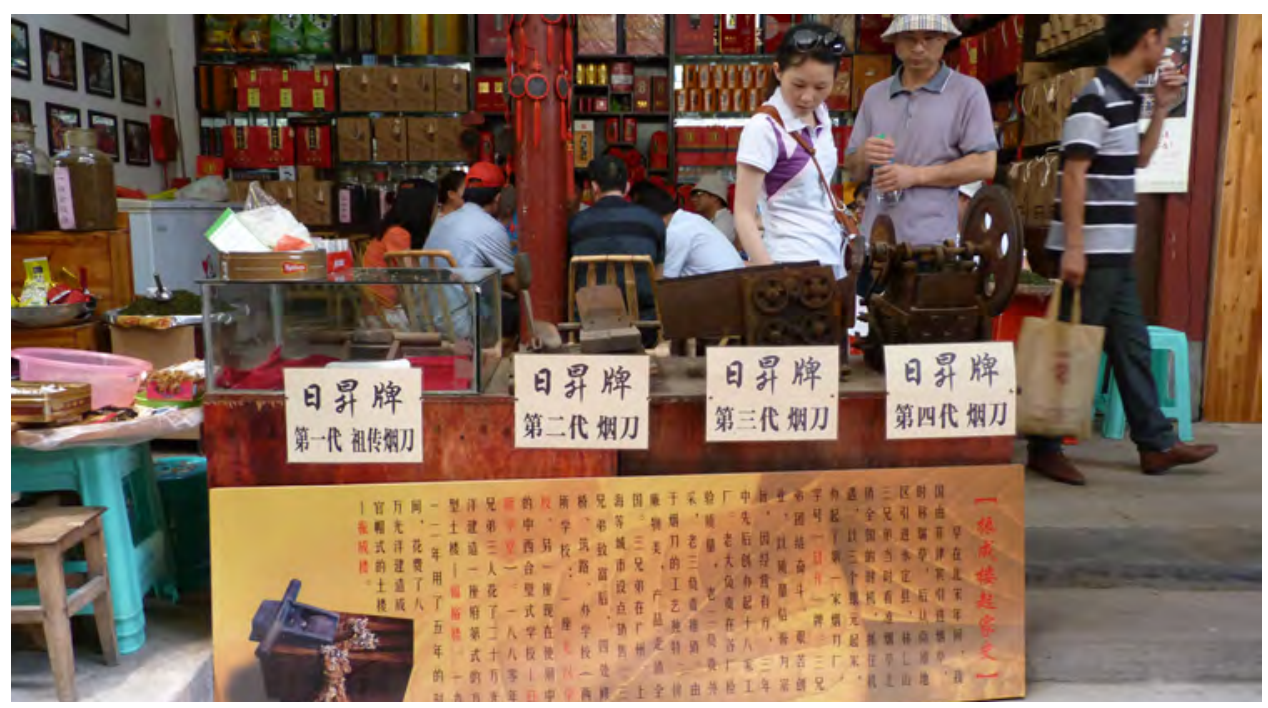

Figure 6: The exhibition of tobacco cutters.

During the period of my fieldwork in the village (2011-2012), the residents still claimed themselves to be farmers rather than businessmen, but in practice their lifestyle was very 
different from an ancestral farming one. Their major work in their daily economic life was drinking tea, chatting with tourists, making rolled cigarettes (as a form of cultural demonstration and display), and selling handmade cigarettes, tea, and other products. Hongkeng used to be a place for tea production. However, most tea trees were dug out for the planting of persimmon trees during the 1990s. Although the tea sold in the village was bought from other places in bulk, the residents claim that the tea was locally produced. Rather than giving tourists the packaged tea displayed on the shelves, the residents tended to package the tea with plain plastic bags under the eye of the tourists. Packing and sealing the tea on the spot is a strategy of de-commodification. The performance of visible local labor, in combination with the narrated history of local tea farming, repositions this non-local tea in a local frame. The intentional act of packing goods at the scene is a staged "back stage" that contributes to creating a sense of authenticity for tourists (MacCannell 1997).

As tulou are put on the national and global stage as a celebrated heritage phenomena and as a tourist destination, local people start to consciously and subconsciously mark and represent their tradition and their identity. Based on their new understanding of tulou and their own identity in what the outside world has perceived as a traditional agricultural society, local people make modifications and even new inventions through reference to the past and through recoding existing symbols to serve current purposes. To some extent the representation is a realization of outsiders' perceptions and imaginations of the local people and place. But local people are not simply enacting a script written by outsiders, they are improvising based not only on the expectations of outsiders but also in relationship with each other and with their own senses of local culture and history.

The representation of local culture and the reorganization of living space within tulou is implicated in heritage tourism as a new form of cultural expression and a new form of daily economy in Hongkeng village. In the service industry-oriented home museum, display and reproduction are characterized by segmentation, merger, rearrangement, contextualization, decontextualization, and recontextualization of cultural elements and of constructions of time and space. Culture and localness, in their own right, take on new meanings and values in new social settings. The history of tulou construction, tobacco cutter production, and tea farming in Hongkeng is a resource for cultural reproduction in transforming a low-density living space into a high-density exhibition space. When tulou as home is converted into a performance stage within in a larger touristic destination, it becomes a tourist cultural space that hybridizes display, touristic narratives, everyday life, and local economy.

This short essay provides only a glimpse of Hongkeng village and the tolou-centered cultural, social, political, and economic transformations underway there (Zhang 2014). My aspiration is to have shared just enough of a report on the village to evoke some sense of the way that museumification is taking place in Hongkeng and in similar places within rural China. Museumification is understood here as the transition or transformation of a living space into an idealized re-presentation of itself. Everything within such a museumified social space is considered not for its actual use in daily life but for its value as a potential museum artifact useful for presentation or representation. As Michael Di Giovine points out in his book The Heritage-scape: UNESCO, World Heritage, and Tourism (2009), such artifacts can be in varying degrees material, such as buildings, tools, industrial centers, markets, or more abstract things such as ethnicity or human beings. Di Giovine continues, "Indeed, instead of collecting, 
documenting, recontextualizaing, and exhibiting objects as a traditional museum does, the ecomuseum collects people and their immaterial activities. Everything becomes an artifact, and every action becomes a performance $(2009,261)$." Hongkeng village as a cultural village is, in essence, becoming such an eco-museum. ${ }^{3}$

\section{Notes}

Editor's Note: The preceding essay was presented by its author during The Fifth Forum on China-US Folklore and Intangible Cultural Heritage: Bridging Tangible and Intangible Cultural Heritage in Ethnographic Museums and Heritage Sites, which was held at the Museum of International Folk Art in Santa Fe, New Mexico, in the United States on November 10-11, 2014. The conference was organized by the American Folklore Society and the China Folklore Society, with sponsorship from The Henry Luce Foundation. The conference was a part of the China-US Folklore and Intangible Cultural Heritage Project, specifically the sub-project on Intangible Cultural Heritage and Ethnographic Museum Practice. The Mathers Museum of World Cultures is an institutional participant in this project.

1. These are themes that I explored in greater depth in "Living with/in Heritage: Tulou as Home, Heritage, and Destination" (Zhang 2014).

2. Most of the visitors are domestic tourists, who are attracted by the symbolized Hakka culture and tulou as a spectacular form of vernacular architecture. There are also diaspora Hakka people who want to find the roots of their ancestors by coming to visit the area.

3. In Hongkeng village, as elsewhere, there are many other forms of presentation, representation, and museumification underway, often pursued through commercial, corporate, nongovernmental, and governmental agencies. The reason that I would pay special attention to local individual agency is that it is an emerging phenomenon of concern in current Chinese society, especially in the realm of tourism. This line of inquiry poses questions regarding what happens when self-conscious representations (=heritage) become reestablished in turn as habitus. This matter is touched upon in work by Kirshenblatt-Gimblett (1998b) and in a project that I am collaborating on with Jason Baird Jackson and Johannes Müske (Jackson, Müske, and Zhang 2015).

\section{References Cited}

Di Giovine, Michael A. 2009. The Heritage-scape: UNESCO, World Heritage, and Tourism. Lanham, MD: Rowman and Littlefield.

Huang, Hanmin 黄汉民. 2009. Fujian tulou—zhongguo chuangtong minju de guibao 福建土楼 一中国传统民居的瑰宝 [Fujian Tulou-Treasure of Chinese Vernacular Architecture]. Beijing: shenghuo, dushu, xinzhi sanlian shudian. 
Jackson, Jason Baird, Johannes Müske, and Lijun Zhang. 2015. "Heritage: What Do American Folklorists Mean by the Term?" Paper presented at the Sixth Forum on China-US Folklore and Intangible Cultural Heritage, Guizhou, China, April 13-14, 2015.

Kirshenblatt -Gimblett, Barbara. 1998a. Destination Culture: Tourism, Museums, and Heritage. Berkeley: University of California Press.

. 1998b. "Sounds of Sensibility." Judaism 47 (1): 49-78.

- 2006. "World Heritage and Cultural Economics." In Museum Frictions: Public Cultures/Global Transformations, edited by Ivan Karp, Corinne A. Kratz, Lynn Szwaja, and Tomas Ybarra-Frausto, 161-202. Durham, NC: Duke University Press. https://doi.org/10.1215/9780822388296

MacCannell, Dean. 1997. "Staged Authenticity: Arrangements of Social Space in Tourist Settings." American Journal of Sociology 97 (3): 589-603.

Nyíri, Pál. 2006. Scenic Spots: Chinese Tourism, the State, and Cultural Authority. Seattle: University of Washington Press.

Pan, Shouyong 潘守永 . 2011. shengtaibowuguan jiqi zai zhongguo de fazhan: lishixing guancha yu sikao 生态博物馆及其在中国的发展：历时性观察与思考 [Ecomuseum and Its Development in China: Chronological Observation and Thinking]. Zhongguo bowuguan Z1: 24-33.

United Nations Educational, Scientific and Cultural Organization (UNESCO). 2008. "Fujian Tulou." Accessed March 22, 2016. http://whc.unesco.org/en/list/1113.

Zhang, Lijun. 2014. “Living with/in Heritage: Tulou as Home, Heritage, and Destination.” PhD diss., Indiana University.

Lijun Zhang is a research curator at the Anthropological Museum of Guangxi. She is co-curator of two recent exhibitions. With Marsha MacDowell, she co-curated Quilts of Southwest China at the Michigan State University Museum. At the Mathers Museum of World Cultures, she cocurated Putting Baskets to Work in Southwestern China with Jason Baird Jackson. She has recently contributed to Cambridge Journal of China Studies and is the editor, with Marsha MacDowell, of Quilts of Southwest China (Bloomington: Indiana University Press, 2016)

https://doi.org/10.14434/mar.v12i1.20731 